\title{
Polyamide profiles of porcine milk and of intestinal tissue of pigs during suckling
}

\author{
D Kelly *, TP King, DS Brown, M McFadyen
}

Rowett Research Institute, Bucksburn, Aberdeen, Scotland AB2 9SB, UK

(Received 9 July 1990; accepted 23 November 1990)

\begin{abstract}
Summary - Previous studies have suggested that luminal polyamines can directly influence intestinal differentiation of neonatal rats. The present investigation has demonstrated the presence of high levels of polyamines in porcine milk and in the intestinal tissues of suckling pigs. The quantities of polyamines in sow's milk sampled between wk 1 and 8 of lactation were determined using high performance liquid chromatography (HPLC). The concentration of milk spermidine (SPD) remained constant over the first 3 to 4 wk of lactation but increased 4 -fold between wk 4 and 7 . Neither putrescine nor spermine (SPN) were detected in any of the milk samples. During intestinal development the mucosal SPD/SPN ratio was elevated between wk 1 and 3 and wk 5 and 7 . The latter period of increase corresponded with the surge in milk SPD concentration. It is suggested that milk SPD is taken up from the intestinal lumen and is involved in potentiating intestinal differentiation during the latter part of the suckling period.
\end{abstract}

polyamine / milk / intestine / disaccharidase / piglet

Résumé - Les profils de polyamines du lait de truie et du tissu intestinal de porcelet allaité. Des études précédentes ont suggéré l'influence des polyamines sur la différenciation intestinale au cours de la vie foetale du rat. Ce travail démontre la présence d'un niveau important en polyamines dans le lait de truie et dans l'intestin grêle de porcelet. La concentration en polyamines du lait de truie échantillonné entre la première et la huitième semaine de lactation a été déterminée par chromatographie liquide haute performance. La concentration de spermidine (SPD) du lait reste constante pendant les 4 premières semaines de lactation, puis elle quadruple entre la quatrième et la septième semaine. La putrescine et la spermine (SPN) n'ont pas été détectées dans les échantillons de lait. Pendant la phase de développement intestinal, le rapport de mucosal SPD/SPN augmente entre la première et la troisième semaine, ainsi qu'entre la cinquième et la septière semaine. Cette dernière période d'augmentation correspond a une élévation de la concentration de SPD dans le lait. II est suggéré que la SPD du lait est prélevée de la lumière intestinale et contribue potentiellement à la différenciation intestinale pendant la dernière période d'allaitement.

polyamine / lait / intestin / disaccharidase / porcelet

${ }^{*}$ Correspondence and reprints. 


\section{INTRODUCTION}

Polyamines are ubiquitous in both prokaryotic and eukaryotic cells and have been shown to facilitate cellular proliferation and differentiation. The biosynthetic enzymes involved in intestinal mucosal polyamine synthesis and the polyamine content of the mucosa show patterns of ontogenic change that can be correlated with those of mucosal disaccharidases in the deve!oping rat (Luk et al, 1980a). Furthermore, the post-natal increase in mucosal enzymes can be delayed by the administration of difluoromethylornithine (DFMO), an inhibitor of ornithine decarboxylase, the rate limiting enzyme in polyamine biosynthesis (Luk et al, 1980b).

Biosynthesis of polyamines, particularly spermidine, is markedly enhanced in the mammary gland during pregnancy and lactation (Russel and McVicker, 1972) and they have been detected in the milk of a number of mammalian species (Sanguansermsri et al, 1974; Brosnan and Yu-Wan, 1985). The aim of the present study was to determine the levels of polyamines in porcine milk during lactation and to describe the ontogenic changes in intestinal tissue polyamine levels in suckling pigs. The results are discussed with regard to the possible role of dietary polyamines in the regulation of intestinal development.

\section{MATERIALS AND METHODS}

\section{Milk collection}

Lactating sows received a single injection of oxytocin to stimulate milk letdown. Milk samples were obtained by manual expression and stored frozen in sterile containers. On the initial day of the experiment the colostrum was thawed, pooled and maintained in a refrigerated tank with gentle agitation to ensure homogeneity. Milk samples were stored at $-20^{\circ} \mathrm{C}$ for approximately $3 \mathrm{~d}$ prior to preparation for polyamine analysis.

\section{Experimental animals}

The progeny for this experiment were derived from 4 sows (Large White $x$ Landrace). Using a combination of concurrent matings and pharmacological manipulations, all sows were farrowed within the same 24-h period. Nine piglets from each sow were taken at birth and housed in sterile incubators $\left(34^{\circ} \mathrm{C}, \mathrm{RH} 50 \%\right)$ for the first $36 \mathrm{~h}$ of life. Each piglet was fed by gavage approximately $40 \mathrm{ml}$ of standard colostrum every 3 $\mathrm{h}$ for $36 \mathrm{~h}$ post-partum. Animals were suckled for 8 wk on single dams housed in farrowing crates $(2.3 \times 1.7 \times 0.6 \mathrm{~m})$ for the duration of the experiment. To avoid solid feed consumption, piglets were removed from the sows during their feeding periods and any spilled food removed. To maintain hygiene the crates were cleaned and disinfected twice daily. One animal per litter was killed at wk 1; thereafter 2 animals per litter were killed at $3,5,7$ and 8 weeks post-partum.

\section{Post-mortem procedure}

Piglets were removed from the sows $2 \mathrm{~h}$ prior to slaughter. Anaesthesia was induced using halohane/oxygen inhalation. A midline laparotomy was performed to expose the intestines. The stomach and the large intestine were sealed with crocodile clips at the pyloric sphincter and the ileocaecal valve respectively. Divisions were made at $10,30,50,70$ and $90 \%$ distance from the pylorus to the ileocaecal valve (sites 1-5 respectively). Ten-cm lengths of small intestine were taken at sites $1-5$, opened along the mesentery, rinsed with $0.14 \mathrm{M} \mathrm{KCl}$, frozen immediately in liquid nitrogen and stored at $-20^{\circ} \mathrm{C}$ for a maximum period of $3 \mathrm{wk}$ prior to analyses.

\section{Polyamine analysis}

Polyamines were extracted from $5 \mathrm{ml}$ of milk and from the mucosa obtained from $10-\mathrm{cm}$ 
lengths of small intestine (SI) (1-2 g wet wt) using $20 \mathrm{ml}$ of $10 \%$ perchloric acid. Polyamines were determined by the high-performance liquid chromatography (HPLC) procedure of Seiler and Knodgen (1980) using a Phillips analytical gradient system and an Altex Uitrasphere IP column ( $5 \mu$ ODS). The internal standard used was 1,7-diaminoheptane dihydrochloride.

\section{Small intestine differentiation indices}

Ornithine decarboxylase (ODC) activity was determined on homogenates preparated from triplicate 2-cm lengths of intestine from each of the 5 intestinal sites according to the method of Russel and Snyder (1968). Preparation of mucosal extracts, dilutions and methods for determination of maltase (EC 3.2.1.3) were as described by Kelly et al (1990). The substrate concentrations and the incubation conditions were as described by Kidder and Manners (1980). Protein, RNA and DNA were determined using the meth- ods described by Bradford (1976), Sneider (1957) and Greer et al (1985).

\section{Statistical analysis}

The data obtained from this study was subjected to an analysis of variance using the Genstat package.

\section{RESULTS}

\section{MIlk polyamines}

The concentration of spermidine ( $\mu \mathrm{mol} / \mathrm{l})$ remained constant over the first 3 wk of lactation, increased 4-fold by wk 7 and decreased by wk 8 (fig 1). Putrescine and

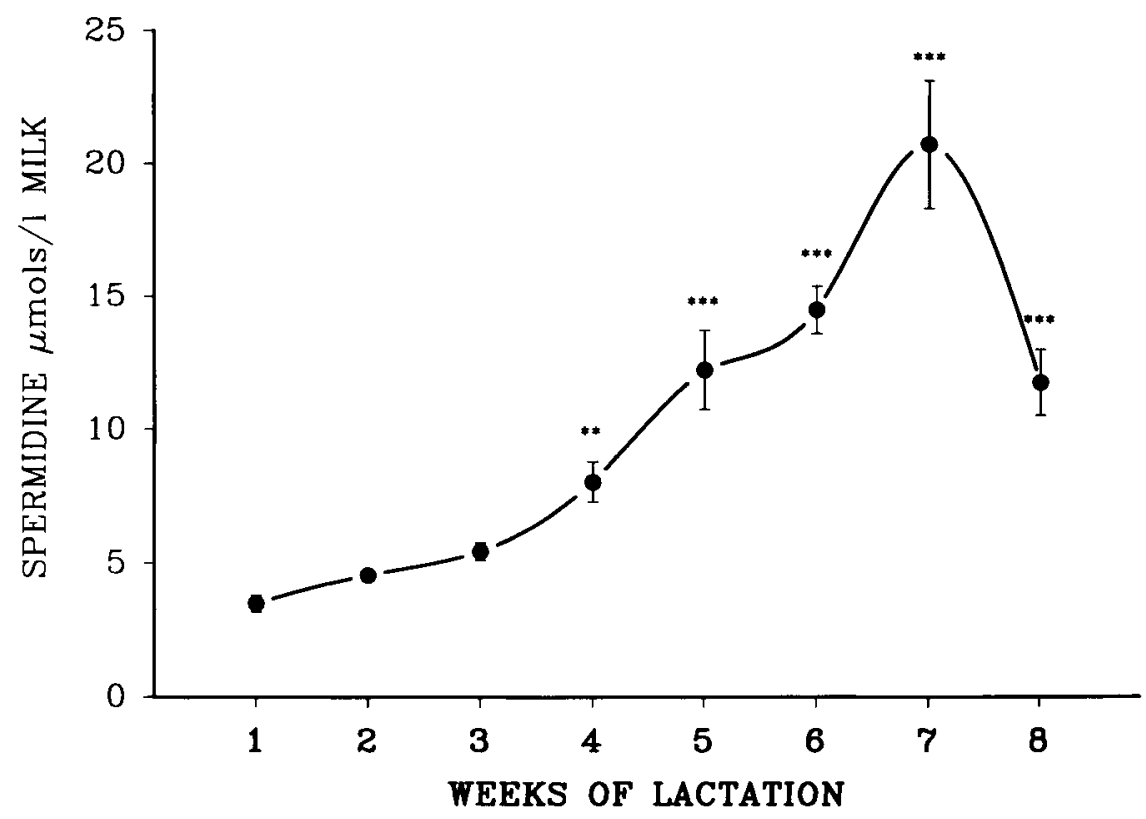

Fig 1. Milk spermidine concentration $(\mu \mathrm{mol} /)$ ) (mean \pm SEM of 3 milk samples per wk obtained from 7 sows during the first 8 wk of lactation). Statistical significance is expressed relative to wk 1 values. ${ }^{* *}=P<0.01 ;{ }^{* * *}=P<0.001$. 
spermine were not detected in the milk samples.

\section{Intestinal polyamines}

Putrescine levels in the intestinal tissue were variable and detected concentrations in the range of $0.04-0.40 \mu \mathrm{mol} /$ per $10-\mathrm{cm}$ length of small intestine (SI). Putrescine was detected at sites 1 and 2 in approximately $80 \%$ of animals but in more distal intestinal sites was detectable in only $40 \%$ of animals. There was no significant age effect on putrescine levels and the detailed data are not presented.
The mean spermidine (SPD) concentration ( $\mu \mathrm{mol} / 10 \mathrm{~cm} \mathrm{SI}$ ) of the 5 intestinal sites significantly $(P<0.001)$ increased between wks 1-7 and then decreased at wk 8 (table I). In contrast, when SPD was expressed per $g$ mucosal protein, the highest value was obtained at wk 1 and then the levels significantly decreased at wk $3(P<$ $0.01)$ and at wk $5(P<0.001)$. However, at wk 7 and 8 a small but conspicuous increase in SPD/g protein was noted (values at wk 8 were $15 \%$ higher than the 5 -wk values).

Spermine (SPN) concentration $(\mu \mathrm{mol} / 10$ cm SI) increased significantly $(P<0.001)$

Table I. Polyamine content, mucosal protein, DNA and RNA content and enzyme activity (mean of 5 sites) of the small intestine of suckled pigs at $1,3,5,7$ and 8 weeks post-partum.

\begin{tabular}{|c|c|c|c|c|c|c|c|}
\hline & \multicolumn{5}{|c|}{ Weeks post-partum } & \multirow[t]{2}{*}{ SED } & \multirow{2}{*}{$\begin{array}{l}\text { Statistical } \\
\text { significance }\end{array}$} \\
\hline & 1 & 3 & 5 & 7 & 8 & & \\
\hline $\begin{array}{c}\text { Spermidine (SPD) } \\
\mu \mathrm{mol} / 10 \mathrm{~cm} \mathrm{SI} \\
\mu \mathrm{mol} / \mathrm{g} \text { protein }\end{array}$ & $\begin{array}{r}2.52 \\
22.12\end{array}$ & $\begin{array}{r}3.03 \\
16.92\end{array}$ & $\begin{array}{r}4.39 \\
14.15\end{array}$ & $\begin{array}{r}5.49 \\
15.17\end{array}$ & $\begin{array}{r}4.81 \\
16.25\end{array}$ & $\begin{array}{l}0.482 \\
2.055\end{array}$ & $* \star * \star *$ \\
\hline $\begin{array}{c}\text { Spermine (SPN) } \\
\mu \mathrm{mol} / 10 \mathrm{~cm} \mathrm{SI} \\
\mu \mathrm{mol} / \mathrm{g} \text { protein }\end{array}$ & $\begin{array}{r}1.67 \\
14.66\end{array}$ & $\begin{array}{r}1.89 \\
10.56\end{array}$ & $\begin{array}{r}5.36 \\
17.28\end{array}$ & $\begin{array}{r}5.61 \\
15.50\end{array}$ & $\begin{array}{r}5.31 \\
17.92\end{array}$ & $\begin{array}{l}0.353 \\
2.041\end{array}$ & 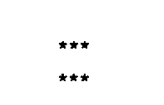 \\
\hline SPD/SPN & 1.51 & 1.60 & 0.82 & 0.98 & 0.91 & 0.101 & $* * *$ \\
\hline $\begin{array}{l}\text { Protein } \\
\mathrm{mg} / 10 \mathrm{~cm} \mathrm{SI}\end{array}$ & 113.9 & 179.0 & 310.2 & 361.9 & 296.30 & 28.22 & $\star \star \star \star$ \\
\hline $\begin{array}{l}\text { DNA } \\
\mathrm{mg} / 10 \mathrm{~cm} \mathrm{SI} \\
\mu \mathrm{g} / \mathrm{mg} \text { protein }\end{array}$ & $\begin{array}{r}3.29 \\
28.89\end{array}$ & $\begin{array}{l}10.72 \\
59.88\end{array}$ & $\begin{array}{l}14.35 \\
46.26\end{array}$ & $\begin{array}{l}17.36 \\
47.97\end{array}$ & $\begin{array}{l}16.38 \\
55.28\end{array}$ & $\begin{array}{r}18.88 \\
9.88\end{array}$ & **** \\
\hline $\begin{array}{l}\text { RNA } \\
\mathrm{mg} / 10 \mathrm{~cm} \mathrm{SI} \\
\mu \mathrm{g} / \mathrm{mg} \text { protein }\end{array}$ & $\begin{array}{r}7.57 \\
66.46\end{array}$ & $\begin{array}{l}11.66 \\
65.14\end{array}$ & $\begin{array}{l}28.32 \\
91.30\end{array}$ & $\begin{array}{l}31.07 \\
85.85\end{array}$ & $\begin{array}{l}24.60 \\
83.02\end{array}$ & $\begin{array}{r}18.90 \\
7.21\end{array}$ & $* * *$ \\
\hline $\begin{array}{l}\text { Maltase } \\
\quad(\mu \mathrm{mol} / \mathrm{min} 10 \mathrm{~cm} \mathrm{Sl})\end{array}$ & 0.19 & 0.12 & 3.99 & 5.37 & 5.92 & 0.558 & $* * *$ \\
\hline
\end{tabular}

SED, standard error of the difference; ${ }^{* * *}, P^{\prime}<0.001$. 
between wk 1 and 5 and remained high for the remainder of the experimental period (table I). SPN expressd per $\mathrm{g}$ protein was significantly lower at wk 3 than at the other post-partum weeks. The ratio SPD/SPN was high at wk 1 and 3 and was significantly $(P<0.001)$ lower during subsequent weeks (table I). The post-partum decline in
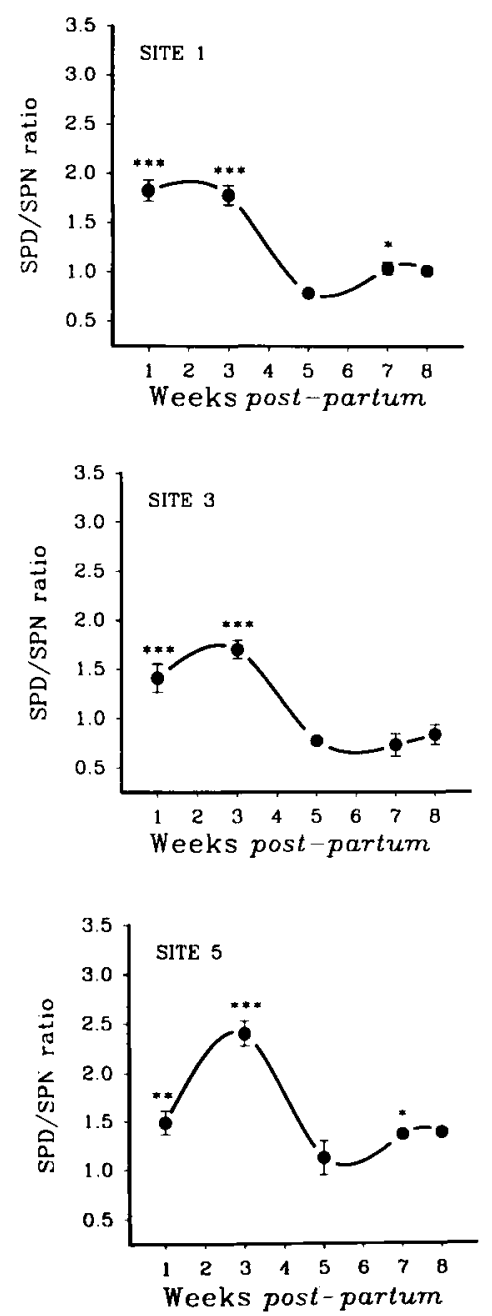

the SPD SPN ratio was evident at all 5 intestinal sites (fig 2). Proportional differences in SPD and SPN levels gave rise to a secondary increase in SPD/SPN ratio between wk 5-7 which just failed to attain statistical significance. However, this effect was significant $(P<0.05)$ at sites 1,2 and 5 (fig 2).
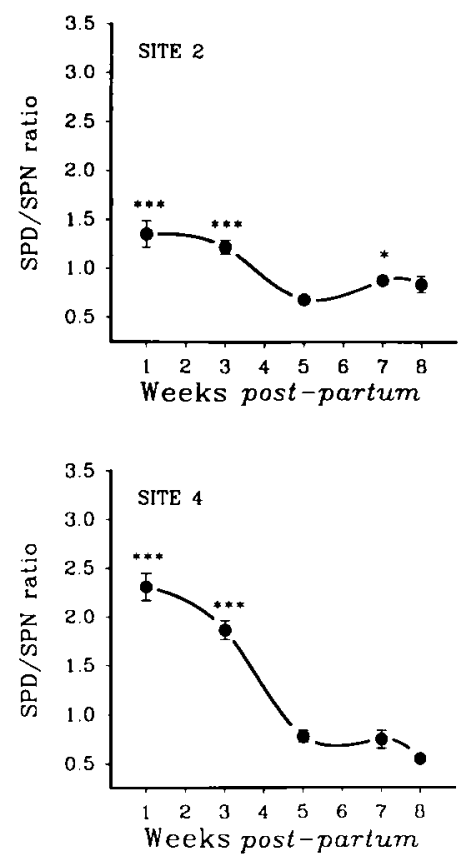

Fig 2. Mucosal spermidine/spermine ratio (mean \pm SEM at 5 intestinal sites) of suckled pigs from 1-8 wk post-partum. Statistical significance is expressed relative to wk 5 data. ${ }^{*}=P<0.05$; ${ }^{* *}=P<0.01$; ${ }^{\star * *}=P<0.001$. 


\section{Small intestine differentiation indices}

Ornithine decarboxylase (ODC) activities ranged from $1.5-30 \mathrm{nmol} / \mathrm{h} / \mathrm{g}$ protein or were below the levels of detection. No significant age effect was observed in ODC activity and detailed data have not been presented. There were no significant time $x$ site interactions for any of the other parameters measured and hence the data presented are the mean values for the 5 intestinal sites. Protein and RNA content $(\mathrm{mg} / 10 \mathrm{~cm} \mathrm{SI})$ increased significantly $(P<$ 0.001 ) between wk 1-5 (table 1). These increases were sustained until wk 7 , but the values were slightly lower at week 8 . DNA levels (mg/10 cm SI) showed a similar increase during the early post-partum period, although the most significant rise occurred between wk 1-3. The early increases in DNA and RNA were also evident when values were expressed per $\mathrm{mg}$ protein. Observed trends in the ontogenic changes of maltase activity was constant irrespective of whether the basis of comparison was per unit protein or per unit length of small intestine. Maltase ( $\mu \mathrm{mol} /$ $\mathrm{min} / 10 \mathrm{~cm} \mathrm{SI}$ ) was low at 1 and $3 \mathrm{wk}$ and then increased greatly between wk 3-8.

\section{DISCUSSION AND CONCLUSION}

The results presented clearly indicate that changes in polyamine levels occur in porcine milk during lactation and in the intestinal tissues of pigs during early post-natal life or during suckling. Polyamine content of milk appears to vary characteristically from one species to another. In the present study the concentration of SPD in porcine milk was found to range from 4-21 $\mu \mathrm{mol} / \mathrm{l}(\approx 20-100 \mathrm{nmol} / \mathrm{g}$ ) milk during lactation. This level is comparable to that of rat milk (40 nmol/g milk) but greater than that in human milk (4 nmol/g milk) (Sanguan- sermsri et al, 1974; Brosnan and Yu-Wan, 1985). In the current study, SPN was not detected in porcine milk although it was previously detected in the studies on rat and human milk. In the rat SPD was the predominant polyamine but the converse was true in human milk. In the current study the concentration of SPD in milk was found to increase $\approx 4$-fold between wk 4-7 of lactation. This is in agreement with the report of Sanguansermsri et al (1974) who described dramatic increases in human breast milk polyamines in the 5th week of lactation. Such changes in SPD concentration during lactation may merely reflect fluctuations in the overall synthetic activity of the mammary gland, but in view of recent studies in the rat (Dufour et al, 1988; Bardocz et al, 1990) it is plausible that milk polyamines are biologically significant to the developing intestine.

The intestine, like other mammalian tissues and cells, requires polyamines for proliferation and differentiation (Luk et al, 1980b; Pegg, 1986). This is the first report of intestinal tissue polyamine levels in neonatal pigs and the data are in good agreement with those published for the neonatal rat (Dufour et al, 1988). Intestinal tissue polyamines originate from several sources including de novo synthesis, translocation from other organs, diet (Bardocz et al, 1990) and luminal bacteria (Osbourne and Seidel, 1989). In the current study, enhanced tissue polyamine levels are likely to be of endogenous and dietary origin since intestinal microbial populations do not change dramatically during suckling (McAllistair et al, 1979).

Putrescine, unlike the other polyamines, was detected at relatively low levels in $\approx$ $40-80 \%$ of suckling pigs depending on the sampling site of the intestine. This is likely to be partially related to the sensitivity of technique and equipment, but may also be related to the rapid catabolic breakdown 
and translocation of putrescine to other sites relative to SPD and SPN (Bardocz et al, 1990). Furthermore, the low levels of both putrescine and ODC in the intestinal tissue might suggest that de novo synthesis is not the main source of polyamines during intestinal maturation, although proof of this would require more acute experimentation.

The levels of intestinal tissue SPD and SPN expressed on a protein basis were found to be high at wk 1 relative to the values determined at the other post-partum weeks. This is consistent with the findings of Bardocz et al (1990) who have shown that during gut hypertrophy, polyamines (particularly SPD) accumulate in the tissue prior to DNA and protein synthesis. Beyond wk 1 the post-partum levels of SPD and SPN expressed on a protein basis were essentially constant. In contrast, SPD and SPN concentrations expressed on a unit length basis increased steadily between wk 1-7 concomitant to the increases in mucosal DNA per unit length. Clearly, where conditions or treatments affect cell proliferation and organ growth, analysis of polyamine data expressed on unit length basis is the more sensitive indicator of biological change.

In the current study, high SPD/SPN ratios at wk 1 and 3 post-partum were coincident with a period of heightened cellular proliferation, as evidenced by the increase in mucosal DNA levels during this period. The SPD/SPN then decreased at wk 5. This is agreement with the observations of Janne et al (1978) who pointed out that high SPD/SPN ratios are generally correlated with rapid cell proliferation and that this ratio decreases with maturity.

In this study, a secondary increase in intestinal SPD/SPN occurred between wk 57 and was coincident with the surge in SPD levels in milk. It has been recently shown that enterocytes from the small in- testine of the rat contain an energydependent transport system for uptake of luminal polyamines (Kumagai et al, 1989). However, Bardocz et al (1990) have recently suggested that luminal uptake of polyamines relies to a large extent on passive diffusion and that uptake is limited only by dietary supply. Oral administration of polyamines to rat pups has been shown to result in enhanced concentrations within the intestinal tissue (Dufour et al, 1988), implying the existence of similar transport mechanisms for luminal uptake in neonates.

The peak in milk SPD concentration at 7 wk was coincident with the peak in mucosal RNA content (per $10 \mathrm{~cm} \mathrm{Sl).} \mathrm{Further-}$ more, the period of rapid increase (wk 3-7) in milk SPD and tissue SPD (per $10 \mathrm{~cm} \mathrm{SI}$ ) corresponded with the rapid increase in maltase activity. Direct experimental evidence for the role of luminal polyamines in neonatal gut differentiation as distinct from the proliferative effects has been provided by Dufour et al (1988) who have shown enzyme induction in response to oral administration of polyamine to suckling rats. It is possible, therefore, that milk SPD can be transported from the intestinal lumen of the suckling pig and may be involved in potentiating aspects of cellular differentiation including the enhanced expression of mucosal RNA and carbohydrase activity.

\section{REFERENCES}

Bardocz S, Brown DS, Grant G, Pusztai A (1990) Luminal and basolateral polyamine uptake by rat small intestine stimulated to grow by Phaseolus vulgaris lectin PHA in vivo. Biochim Biophys Acta 1034, 46-52

Bradford M (1976) A rapid and sensitive method for the quantitation of microgram quantities of protein utilising the principle of protein-dye binding. Anal Biochem 72, 248-254 
Brosnan ME, Yu-Wan HU (1985) Synthesis and function of polyamines in mammary gland during lactation. Recent Prog Polyamine Res (Selmeci L, Brosnan ME, eds) 169-179

Dufour $C$, Dandrifose $G$, Forget $F$, Vermesse F, Romain N, Lepoint $P$ (1988) Spermine and spermidine induce intestinal maturation in the rat. Gastroenterology 95, 112-116

Greer F, Brewer AC, Pusztai A (1985) Effect of kidney bean (Phaseolus vulgaris) toxin on tissue weight and composition and some metabolic functions in rats. $\mathrm{Br} J$ Nutr 54, 95 103

Jänne J, Pösö H, Raina A (1978) Polyamines in rapid growth and cancer. Biochim Biophys Acta 473, 241-293

Kelly D, Smyth JA, McCracken KJ (1990) Effect of creep feeding on structural and functional changes of the gut of early-weaned pigs. Res Vet Sci 48, 350-356

Kidder DE, Manners MJ (1980) The level and distribution of carbohydrases in the small intestine mucosa of pigs from 3 weeks of age to maturity. Br J Nutr 43, 141-153

Kumagai J, Jain R, Johnson LR (1989) Characteristics of spermidine uptake by isolated rat enterocytes. Am J Physiol 256, G905-G910

Luk GD, Marton LJ, Baylin SB (1980a) Ornithine decarboxylase is important in intestinal mucosal maturation and recovery from injury in rats. Science 210, 195-196

Luk GD, Theodore MB, Baylen SB (1980b) Diamine oxidase (histaminase). A circulating marker for rat intestinal mucosal maturation and integrity. $J$ Clin Invest 66, 66-70

McAllistair JS, Kurtz HJ, Short EC (1979) Changes in the intestinal microflora of young pigs with post-weaning diarrhoea or edema disease. J Anim Sci 49, 868-879

Osbourne DL, Seidel ER (1989) Microfloraderived polyamines modulate obstructioninduced colonic mucosal hypertrophy. $A m J$ Physiol 256, G1049-G1057

Pegg AE (1986) Recent advances in the biochemistry of polyamines in eukaryotes. Biochem J 234, 249-262

Russel DH, McVicker TA (1972) Polyamine biogenesis in the rat mammary gland during pregnancy and lactation. Biochem J 130, 7176

Russel D, Synder SH (1968) Amine synthesis in rapidly growing tissues. Ornithine decarboxylase activity in regenerating rat liver, chick embryo and various tumours. Biochemistry $60,1420-1427$

Sanguansermsri J, Gyorgy P, Zilliken F (1974) Polyamines in human and cow's milk. $A m J$ Clin Nutr 27, 859-865

Seiler N, Knodgen B (1980) High performance liquid chromatographic procedure for the simultaneous determination of the natural polyamines and their monoacetyl derivatives. J Chromatogr 221, 227-235

Sneider WC (1957) Determination of nucleic acids in tissues by pentose analysis. Methods Enzymo/ 3, 680-684 